\title{
MINIMAL CLOSURE IN CLEFT LIP AND PALATE SURGERY
}

\author{
D. H. WALKER, F.R.C.S. \\ Senior Plastic Surgeon, fohannesburg Hospital
}

It is a frequently accepted surgical principle that one should do as much as possible for any one patient at a given operation. Cutting across this is the slightly mocking injunction of the late Sir Harold Gillies: "Never do today what you can legitimately put off until tomorrow." Is this an "easy out" for actually or potentially lazy surgeons or can the patient possibly benefit from this startling proposition?

After careful thought, painstaking cephalometric measurements and long periods of follow-up and evaluation, we have an answer, at least in part, from Slaughter and his associates in Chicago, relating to operations and other treatment in patients with cleft lip and palate. This work is not new (papers were published in 1949, I954 and 1958) but forgotten or disbelieved or neglected for a variety of reasons. Among these reasons is probably the understandable feeling of satisfaction at the appearance of completeness in the early period after operation.

Historical Aspects. Faced with the frightening cavities of a complete bilateral cleft lip and palate, a sense of panic sometimes intrudes and the cry goes up to close it quickly and close it all in a desperate hurry. This used to be attempted of course, as early as the sixteenth century and Arthur Barsky, a New York plastic surgeon, reports that cleft lip surgery is said to have been performed in China in the Chin dynasty (A.D. 229-3I7) but it is apparently almost impossible to separate myth and fact in accounts of early Chinese surgery. It is generally concluded that Pierre Franco's account of surgical closure of cleft lips published in the mid-sixteenth century is probably the first published. How much credit is due to the great Ambroise Paré, the dominating figure in French surgery at that time, and how much to Franco, his apparently more modest contemporary, is unknown.

At first the lip operation was a crude pulling together of the cleft margins and transfixion by pins, the whole being held by a figure of eight of waxed thread wrapped around the projecting ends of the pins about eight or ten times. Where the gap was wide Franco advised relaxing incisions inside the mouth.

There was little advance on this until the nineteenth century and closure of the cleft palate was almost impossible until general anaesthesia developed in the Igth century.

With the patient unconscious under an anaesthetic, it is regrettable to note that surgical violence in this field increased. Forcible manipulation and breaking of parts of the alveolar arch with savage displacement and 
frequent amputation of the projecting premaxilla became common. Ruthless undermining of soft tissues outside and inside the mouth enabled these soft parts to be brought together, but only many years later was it recognised that some patients, who had been subjected to such surgical barbarism had, in adult life, definite patterns of deformity and disproportion in their faces. This was almost certainly due to the gross interference with blood supply of the bones forming the middle third of the facial skeleton.

Holdsworth records that as early as 1864 Simon suggested that force was not necessary and that the pressure of the united lip was sufficient to reduce the projection in the infant. His suggestion does not seem to have been taken very seriously until Julius Wolff in 1886 advanced the same idea. He also recommended the closure of bilateral clefts in two stages. Thereafter the body of conservative opinion grew, though the subperiosteal fracture or resection of the septum remained a common feature of operation in extreme cases.

Growth of the Facial Area. The probable normal growth stimulus for the central area of the face starts as far back as the base of the skull (Fig. I). The "driving force," as it were, proceeds in a long curved line (shown dotted), directed by the vomer and transmitted, ultimately, as forward growth of the tip of the nose and upper lip. The structures concerned in this midline growth plane also form the bony and cartilaginous septum between the two halves of the nose.

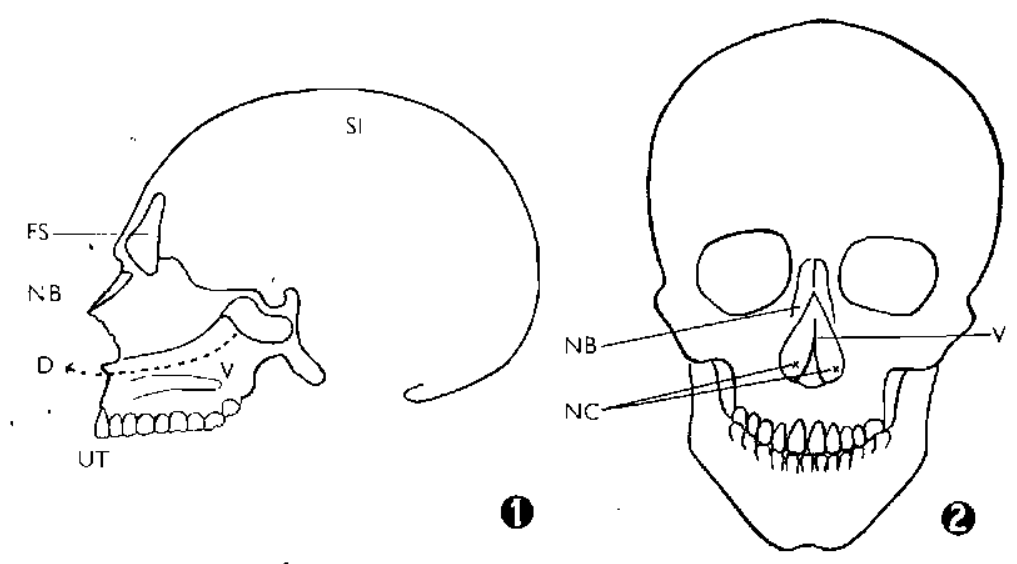

Fig. 1. Sagittal section of the skull. SI : Skull interior. FS : Frontal sinus. NB: Nasal bone. UT: Upper teeth. D: Direction of growth of mid-third of face and tip of nose. V: Vom Fig. 2. Anterior aspect of the skull. NB: Nasal bones. NC: Nasal cavity. V: Front view of nasal septum (vomer).

In effect then, a face grows not from where it appears to grow, for example, at the tip of the nose or by an advancing upper lip, but by development far behind and above these regions. A frontal view of the region affected by this process may be seen in Fig. 2. 
No one knows the detailed plan of the blood supply to growth centres in these regions. Nor is it known how much of the soft tissue can safely be stripped off the bone and moved elsewhere in operations for the closure of cleft lip and palate.

Carried to a literal and over-logical conclusion, one would be afraid to operate on a cleft lip or palate as long as any growth at all is going on. In practice it is believed that sufficient activity of the growth centres has taken place by about the age of four years to make any reasonably radical operation safe from the growth point of view.

Apart from sheer growth, there must be a consideration of what may be described as "moulding forces." These are essentially derived from muscle action in the face, lip, tongue, soft palate and pharynx.

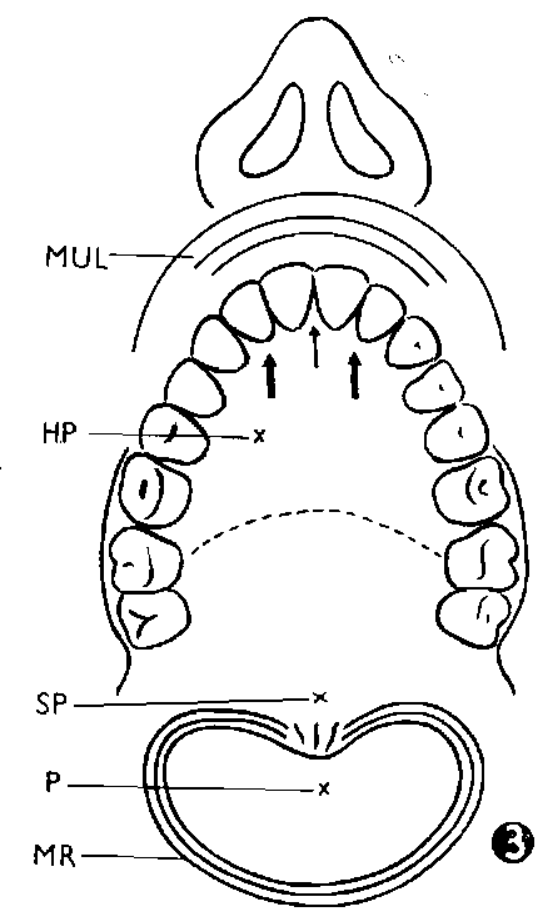

Fig. 3. Diagram of palate, lip and nose from below. MUL: Muscle in upper lip. HP: Hard palate. SP: Soft palate. P: Pharynx. MR: muscle ring.

A diagrammatic representation of a normal nose, lip, palate and pharynx (Fig. 3) helps to present the concept of a band of muscle in the lip constantly acting across the bone beneath the nose and the alveolar arch bearing the teeth. The arrows show the direction of forward growth, which is almost certainly modified by the muscle in two planes.

It is also reasonable to believe that the muscle ring of the mouth, as represented in Fig 3, constantly exerts similar forces in a third plane.

Journal of the South African Logopedic Society, Vol. 13, No. I: May 1966 
Farther back the muscle of the soft palate acts in a variety of directions as does that forming the pharynx. One comes to regard the muscular moulding forces of the lip, palate and pharynx as composed largely of two rings, a "mouth muscle ring" and a "palato-pharyngeal muscle ring."

Apart from the normal moulding forces, it is clear that there must be a tendency to unrestrained and unmodified growth in certain directions if these rings are open, interrupted or undeveloped. This, of course, is exactly the situation which pertains in a patient who has a cleft lip and palate.

We now near a possible answer to our originally quoted suggestion from Sir Harold Gillies.

Principles and Practice. As in many awkward problems, the answer is a compromise. In this instance, the compromise takes the form of starting a process by a surgical operation, which we hope will be advanced and even concluded by natural processes.

If we refer to Fig. 4, it can readily be appreciated that joining muscle in the lip across the cleft must tend to produce a backward pressure on the major alveolar segment, as well as a tendency for the major segment to move towards the side of the cleft. This possible movement can be taken advantage of not only surgically, but by means of an orthodontic appliance. This latter method is probably the major advance since the plan was originally put forward by Slaughter and his colleagues.

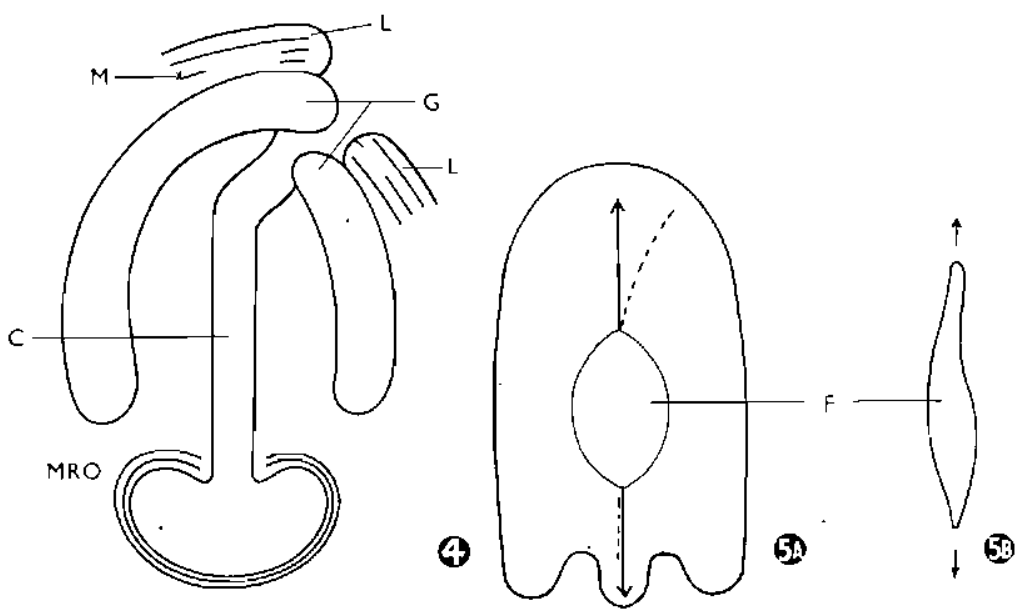

Fig. 4. Cleft lip and palate from below. L: Lip. G: Gum. C: Cleft. MRO: Muscle ring open. M: Muscle.

Fig. 5. Residual fistula (F) in partly repaired cleft narrows later.

Slaughter's original views suggested that in wide clefts where it is almost impossible to get a normal appearance at the first operation, one should be satisfied with any joining of muscle across the cleft lip and gum. This region is then left to the consequences of the surgical dictum that having put normal parts in as near as possible to the normal position, natural

Tydskrif van die Suid-Afrikaanse Logopediese Vereniging, Vol. I3, Nr. I: Mei 1966. 
growth forces should be allowed to exert themselves for a period of years.

If we now apply this principle to the cleft in the soft palate, whether it is part of a complete cleft or a cleft of the soft palate alone, it will be seen that the joining of the muscle in the region of the uvula or as far forward as can be done without undue tension, must exert all the force produced by an intact palato-pharyngeal muscular ring.

However, this must not be taken literally as a representation of the short term result of joining a band of muscle across the lip cleft to complete as much as possible of the muscular ring in relation to the palate and pharynx. The intervening unclosed cleft is deliberately left, with the possible exception of closure of the anterior portion of the hard palate cleft by a vomerine flap.

We must now attempt to visualise growth in about 3 places in different directions at the same time:

I. The forward growth of the middle third of the face already described, which will have the effect of lengthening the overall front to back dimension of the palate.

2. At the same time muscular forces in the lip are at work.

3. Soft palate and pharynx muscles are working from side to side and in a circular manner.

As a result of the interplay of these forces, it is believed that a large number of the residual elliptical clefts change their shape as the years go by. In the favourable case this change of shape takes the form of a long, narrow ellipse replacing the shorter, wider oval that remained immediately after the surgical closure in front of and behind it. (Fig. 5.)

This approach to the whole problem based on the anatomical and physiological features outlined, is being tried at our unit in the Johannesburg Children's Hospital, with the assistance of our orthodontic colleagues, who are keeping a close watch on the shape of the residual cleft in children, who have had muscular closure in front of and behind this cleft. They are able to achieve quite satisfactory speech results with an obturator. This appliance has, of course, to be re-made fairly frequently as the child grows and as the snape of the residual central defect alters. This may, however, be a justifiable period of inconvenience in view of the fact that we hope by this method, to avoid the sometimes severe disproportion in growth of the facial skeleton, which is likely to follow the radical operation at an early age.

The final point is usually raised in the question of when, if at all, any operation may be needed. We believe that nearly all patients need another operation for eventual closure of the central residual cleft. This may be safely left until the age of 12 or 14 years, when one hopes that the edges of the cleft will be so closed together that the final operation will be relatively easy to perform and cause little distress for the patient.

\section{Opsomming}

Hoewel Slaughter en sy kollegas reeds in I949, I954, I958 'n meer konserwatiewe benadering aanbeveel het by die behandeling van lip- en verhemeltesplete is hulle werk vergeet of geïgnoreer, en in elk geval nie algemeen aanvaar nie. 
Die oorspronklike operasies op gesplete lip en verhemelte was baie radikaal en die katastrofiese gevolge hiervan het dikwels eers na jare tot openbaring gekom in die vorm van wanontwikkeling van die gesigskelet met gevolglike disproporsie van 'n kenmerkende aard. Hierdie toestand was byna sonder twyfel die gevolg van belemmerde bloed toevoer na die ontwikkelende skelet in die middelste derde van die gesig. Geleidelik het 'n konserwatiewe benadering egter begin posvat en is die belangrikheid besef van 'n gehegde lip oor 'n onderliggende spleet om die vervorming van abnormale strukture te bewerkstellig. Hierdie werking is die gevolg van die kragte wat uitgeoefen word deur die palato-faringeale, en mondspierkringe in drie vlakke op omliggende benige dele. Wanneer die spierkringe defek is weens 'n spleet vind ongebonde groei plaas, en die gevolge word duidelik gesien in sommige volwasse persone met 'n lipof verhemeltespleet.

Slaughter se benadering kom daarop neer dat die spierkring op 'n vroeë stadium herstel word met minimale versteuring van groeiende weefsel. Dit gee dan die spleet 'n kans om nouer te word saam met die normaalontwikkelende groeiende skelet. Op 'n latere stadium word die spleet dan finaal geheg.

Hierdie vorm van behandeling word tans op die proef gestel in die Johannesburgse Kinderhospitaal in samewerking met die ortodontiese afdeling. In gevalle met erge verplasing van die premaxilla word kort na geboorte 'n prostese gemaak wat druk daarop uitoefen om dit terug te druk na die versteurde alveolêre boog voordat die lipspierkring gesluit word. 'n Obturator-plaat word gedra nadat die sagte verhemelte spierkring geheg is tot op die stadium wanneer die finale operasie uitgevoer word op 'n ,veilige" ouderdom van I 2 tot 14 jaar of meer.

I would like to thank Mr. H. C. de Wet for the Afrikaans summary of this paper.

\section{REFERENCES}

Slaughter, W. B. and Brodie, A. G. (1949): Plast. Reconstr. Surg., 4, 3 I I.

Slaughter, W. B. and Pruzansky, S. (I954): Plast. Reconstr. Surg., 13. 34 I.

Slaughter, W. B. and Pruzansky, S. (1959): The Rationale for Velar Closure as a Primary Procedure in the Repair of Cleft Palate Defects, Plast. Reconstr. Surg., 23, 30I.

Holdsworth (1957): Cleft Lip and Palate. 